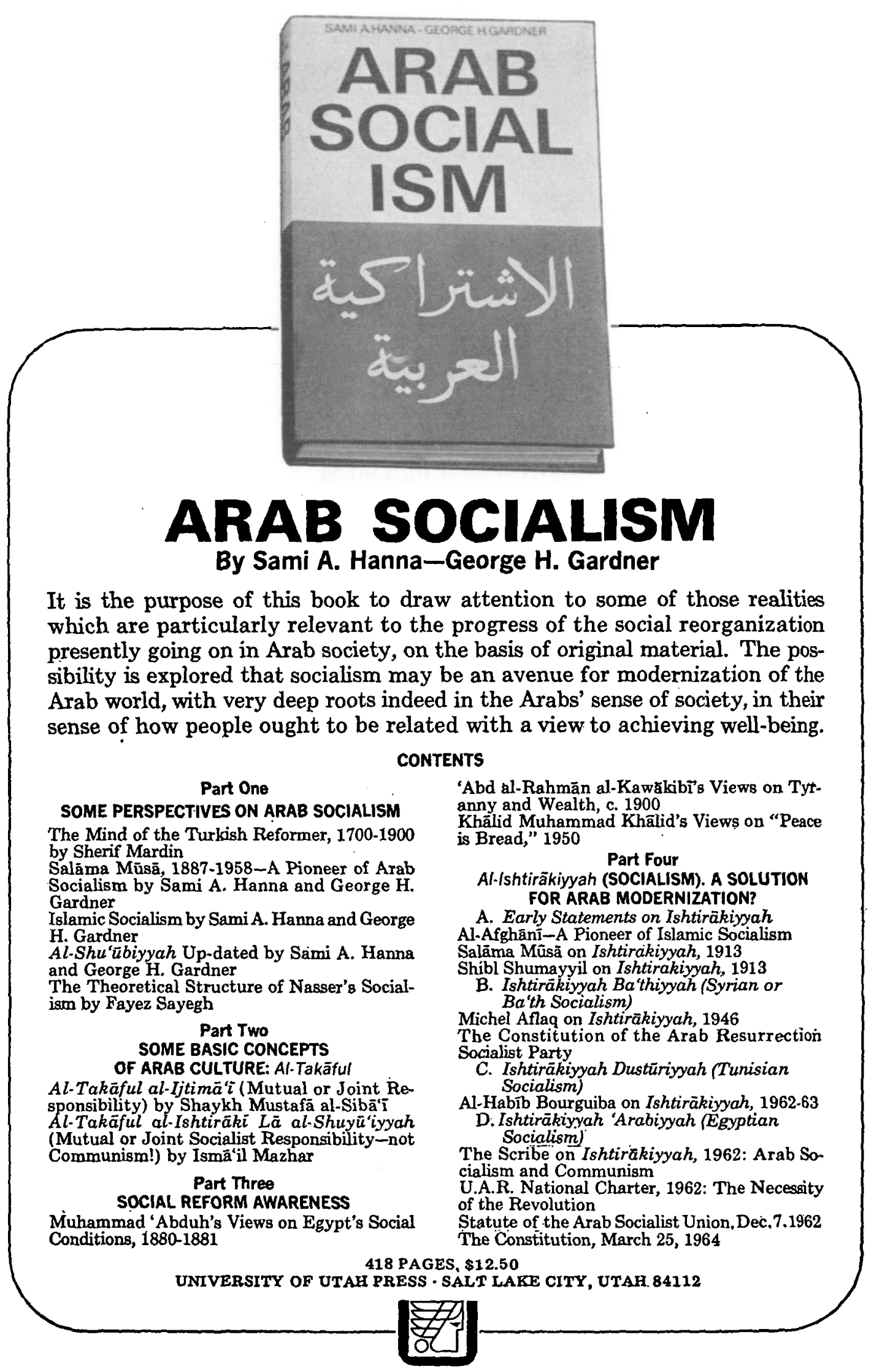




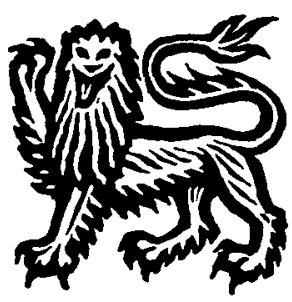

\section{The Cambridge History of Islam}

Volume I: The Central Islamic Lands

Volume II: The Further Islamic Lands: Islamic Society and Civilization

Edited by P.M. HOLT, ANN K. S. LAMBTON and BERNARD LEWIS

This work, written by a team of specialist historians, surveys the history of the Muslim lands over more than thirteen centuries, beginning with Arabia before the Prophet Muhammad. There are numerous maps and a section of photographs (many previously unpublished) illustrating Islamic art and architecture.

Volume I $£ 6$ net

Volume II $£ 7$ net

\section{Islam in Egypt Today}

Social and Political Aspects

of Popular Religion

MORROE BERGER

A study of religious organizations focusing particularly on their social and political roles. The author shows that despite many social changes and 'modernization', religion is still very much alive and important in Egypt.

f2 net

CAMBRIDGE UNIVERSITY PRESS

(ii) 


\section{Middle Eastern Cities}

Ancient, Islamic, and Contemporary Middle Eastern Urbanism: A Symposium

Edited by Ira M. Lapidus

What is distinctive about the cities of the Middle East? What role did they have in the formation of the larger civilizations of which they are a part? These are among the problems posed in this symposium, the first in which archaeologists, historians, economists, anthropologists, and sociologists have brought their skills and accumulated knowledge to the subject.

$$
1970 \text { LC: 72-81939 255 pages map } \$ 6.00
$$

\section{Marsbal Lyautey's Administration of Morocco, 1912-1925}

\section{Alan Scham}

Filling a gap in North African and French colonial history, this study jlluminates the complexities and rationale of colonial rule. The volume begins with a biographical sketch of Marshal Hubert Lyautey, concentrating on his term as Resident General in the Sherifian Empire, a period that saw the establishment of the key institutions of the Protectorate. Later chapters describe the organizational changes that the French affected in four areas: government, property administration, education, and the judiciary.

$$
1970 \text { LC: } 74-92680350 \text { pages maps } \$ 8.75
$$

\section{Arabic Writing Today}

The Sbort Story

\section{Edited by Mahmoud Manzalaoui}

These thirty-three short stories selected from the literary pages of daily newspapers represent the immediate and contemporary voice of the Arabs. The stories, featuring a blend of fanciful and real, reveal the intellectual, social and political fermentation of the post-war years. They are indicative of the literary renaissance in the Arab world and collectively they represent the preoccupations and tensions of the society that produced them.

$$
1970 \text { LC: } 70-960429 \quad 408 \text { pages } \$ 7.50
$$

\section{Politics and Government in Turkey}

\section{H. Dodd}

The only comprehensive study of politics and administration in modern Turkey, this work examines in detail the nature and effects of the extensive reforms started after the revolution of I 960 . Mr Dodd first describes the Ottoman legacy to modern Turkey and the peculiar problems of the Turkish Republic between 1923 and 1960. Special attention is paid to the innovations made by the military in the Turkish administrative system.

$$
1969 \text { LC: } 7^{8-85453} 335 \text { pages } \$ 7.95
$$

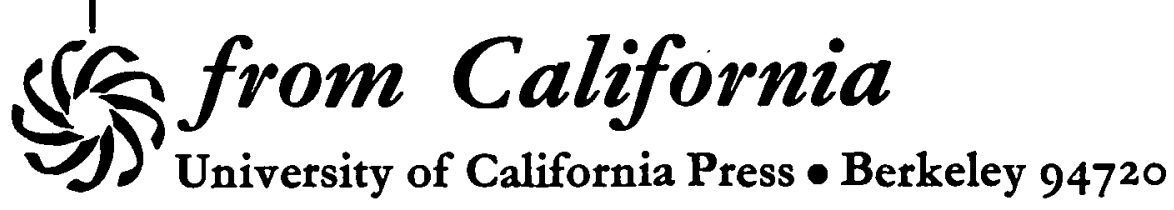

(iii) 
A comprehensive study of political systems in the Middle East

GOVERNMENTS AND POLITICS OF THE CONTEMPORARY MIDDLE EAST

\author{
By TAREQ Y. ISMAEL \\ University of Calgary \\ AND OTHERS
}

Governments and Politics of the Contemporary Middle East is the first up-to-date volume that brings together for the novice in Middle Eastern studies pertinent background material, the pervasive fundamental changes that have been occurring since World War II, and the specific political situation in each country. This text and reader provides the beginning student with a cognizance of the basic factors shaping the area.

The book is divided into four parts. Part I is designed to provide a general overview of the Middle East's physical and social geography and history up to World War II. Part II is an examination of the forces that have shaped contemporary Middle Eastern politics; Islam, nationalism, modernization, and current political trends. Part III is a study of the comparative politics of the Middle East with emphasis on the political institutions and processes, and the domestic and foreign policies of each country. Finally, Part IV describes the historic development and present circumstances of the Middle East's international relations. sos pages \$9.95.

\section{THE DORSEY PRESS}

Homewood, Illinois 60430
Otber Cambridge Area Studies Journals

Journal of American Studies now published 3 times a year

Journal of Latin American Studies publisbed twice a year

Journal of Modern African Studies

publisbed quarterly

Modern Asian Studies

published quarterly

Slavonic and East European Review publisbed quarterly

Please write for further information and a specimen copy to:

CAMBRIDGE UNIVERSITY PRESS

Journal Sales Promotion Cambridge University Press P.O. Box 92, London N.w. X or

32 East 57th Street

New York, N.Y. I0022 
RECENTLY PUBLISHED...

\section{THE TOPOGRAPHY OF BAGHDAD IN THE EARLY MIDDLE AGES}

\section{Text and Studies}

\section{by Jacob Lassner}

This book presents a translation and critical study of the introduction to the Khatib al-Baghdadi's History of Baghdad, the most significant statement preserved from the Early Middle Ages on the architecture, city planning, and, in general, the historical growth of a major Islamic city.

Professor Lassner's work is divided into two parts : a fully annotated translation of the text and a series of studies which trace the historical pattern of the city's development in the Early Middle Ages. The result is the first English translation of this important work and a series of supplementary studies which, based on new historical and archeological materials, suggests to the author a pattern of development quite different than that found in the theories of earlier scholars.

Jacob Lassner is associate professor of Near Eastern languages and literatures at Wayne State University.

\section{SOON TO BE PUBLISHED...}

\section{THE HEJAZ RAILWAY \\ AND THE MUSLIM PILGRIMAGE}

\section{A Case of Ottoman Political Propaganda}

\section{by Jacob M. Landau}

This book comprises an introduction to, annotated translation, and transcription of the original text of an exceedingly interesting Arabic manuscript entitled 'The Book of the Increasing and Eternal Happiness in the Hejaz Railway', a piece of political propaganda written in 1900 by Muhammad 'Arif of Damascus.

Professor Landau, who discovered the manuscript in the Yildiz Palace Collection, University Library, Istanbul, writes in the Introduction that it is an 'almost complete account of the Syrian pilgrimage route and of the Bedouin tribes adjoining it', and continues, 'it is also apparently the very last Muslim account of this pilgrimage, still using camels and donkeys for transportation and ceremoniously adhering to the accustomed pomp'.

In addition to the manuscript, Professor Landau traces the development of railway organization and construction in the Ottoman Empire in general and specifically deals with the history of one of the least-known aspects of Ottoman propaganda in the Arab lands, the building of the Hejaz Railway and its relation to the Muslim pilgrimage.

Jacob M. Landau is associate professor of political science, Hebrew University, Jerusalem.

320 pages

about $\$ 14.95$

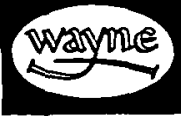

Wayne State University Press

Detroit, Michigan 48202 


\section{ENGLISH TRANSLITERATION SYSTEM}

\section{CONSONANTS}

Column Headings: $\mathrm{A}=$ Arabic, $\mathrm{P}=$ Persian, $\mathrm{OT}=$ Ottoman Turkish, $\mathrm{MT}=$ Modern Turkish

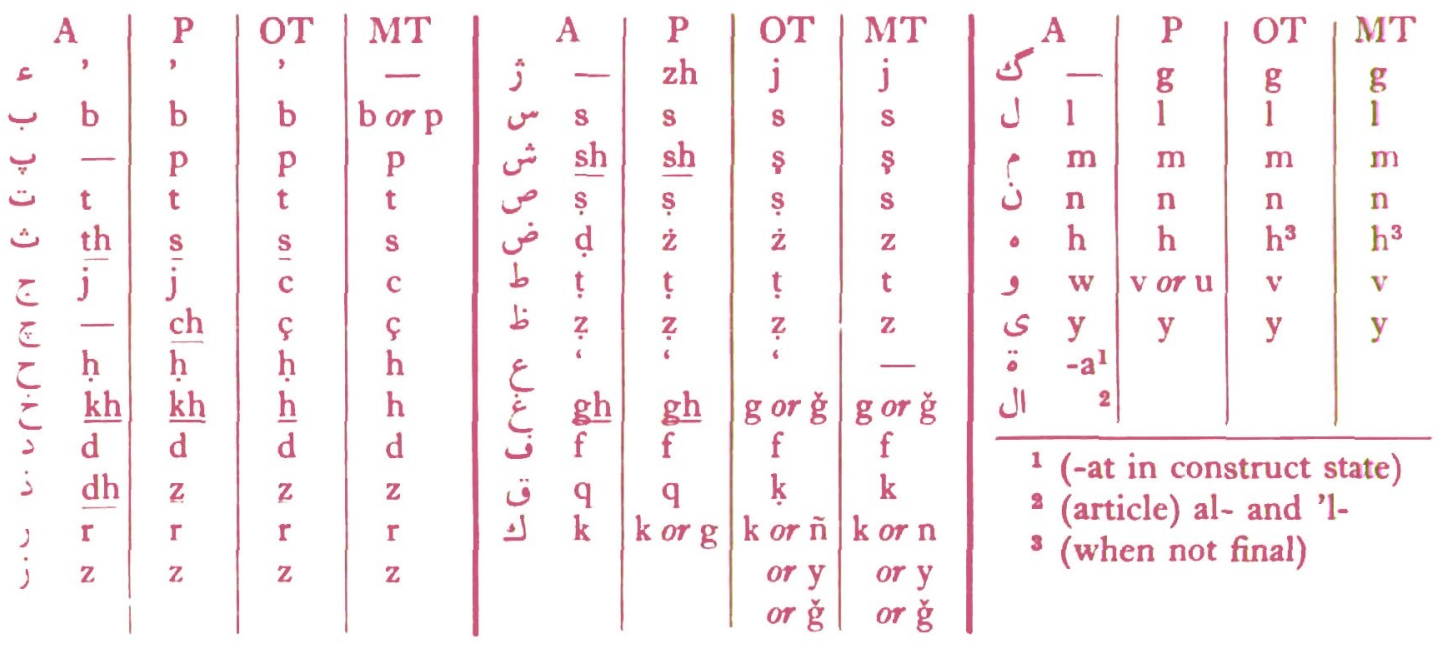

\section{VOWELS}

ARABIC AND PERSIAN

$$
\begin{array}{rr}
\text { Long I or 's } & \text { â } \\
\text { g } & \hat{u} \\
\text { ي } & \text { i }
\end{array}
$$

Doubled $\quad \because$ iyy (final

form î)

, uww (final

form û), etc.

Diphthongs $g^{-}$au or aw

$\varsigma^{-}$ai or ay

Short -

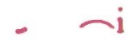

OTTOMAN TURKISH

MODERN TURKISH

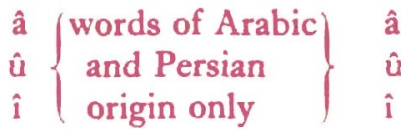

iy (final

form i)

uvv

uvv

iy (final form i)

ev

ev

ey

ey

$\begin{array}{ll}\text { a or } \mathrm{e} & \text { a or } \mathrm{e} \\ \mathrm{u} \text { or } \ddot{\mathrm{u}} & \mathrm{u} \text { or } \ddot{\mathrm{u}} \\ \text { o or } \ddot{\mathrm{o}} & \text { or } \ddot{\mathrm{o}} \\ 1 \text { or } \mathrm{i} & 1 \text { or } \mathrm{i}\end{array}$

For Ottoman Turkish, authors may either transliterate or use the modern Turkish orthography. Articles submitted in French and German may be transliterated according to the systems common in those languages. 
Int. F. Middle East Stud.

\section{CONTENTS}

THE EDITOR'S DESK

$1-2$

NIKKI R. KEDDIE The Iranian Power Structure and Social Change 1800-1969: An Overview

Avigdor Levy The Officer Corps in Sultan Mahmud II's New Ottoman Army, 1826-39

Yusif A. SAyigh Problems and Prospects of Development in the Arabian Peninsula

Paul G. Forand The Relation of the Slave and Client to the Master or Patron in Medieval Islam

LENN E. Goodman Ghazâlî’s Argument from Creation (I)

\section{The Middle East Studies Association of North America, Inc.}

This association was founded in 1966 in order to promote high standards of scholarship in the field of Middle Eastern studies and to facilitate communication among scholars through meetings and publications. In addition to sponsoring the foumal, which is published for the Association by Cambridge University Press, MESA publishes a Bulletin periodically, holds an Annual Conference, and provides other professional services for its members from time to time. Enquiries concerning membership, which includes subscription to the International Fournal of Middle East Studies, should be addressed to: Headquarters and Secretariat, Middle East Studies Association, New York University, Washington Square, New York, N.Y. 10003 , U.S.A. Fees are as follows: Fellows and associates residing in the United States and Canada, \$15; outside the United States and Canada, \$12.00; students, \$6; institutions, \$25.

\section{CAMBRIDGE UNIVERSITY PRESS}

Bentley House, 200 Euston Road, London NW I 2 DB American Branch: 32 East 57th Street, New York, N.Y. 10022

Price $\oint_{0}$. 30 (\$4.00 in U.S.A.) Subscription price $\ell_{4}\left(\$_{12.50}\right.$ in U.S.A.) 